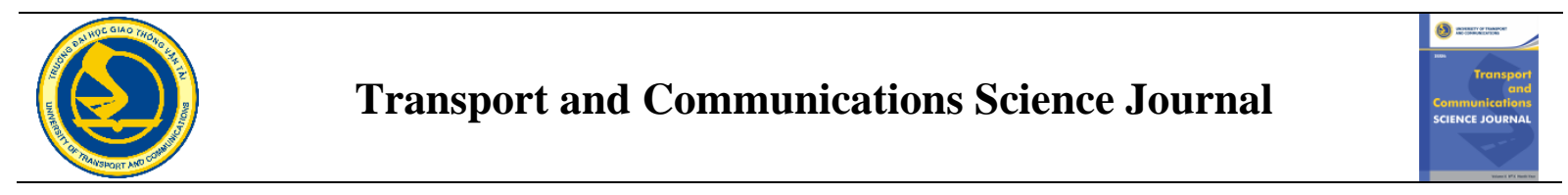

\title{
INVESTIGATION OF SALTWATER INTRUSION IN THACH HAN RIVER SYSTEM BY MIKE HYDRO RIVER PACKAGE
}

\author{
Vuong Tai Chi ${ }^{1}$, Nguyen Khanh Linh ${ }^{1}$, Vu Huong Ngan ${ }^{2}$, \\ Dinh Nhat Quang, ${ }^{3, *}$, Truong Van $\mathrm{Anh}^{4}$
}

\author{
${ }^{1}$ Thuyloi University, 175 Tay Son, Dong Da, Hanoi, Vietnam \\ ${ }^{2}$ International Center of Tropical Agriculture, Pham Van Dong, Hanoi, Vietnam \\ ${ }^{3}$ Thuyloi University, 175 Tay Son, Dong Da, Hanoi, Vietnam \\ ${ }^{4}$ Hanoi University of Natural Resources and Environment, Hanoi, Vietnam
}

\section{ARTICLE INFO}

TYPE: Research Article

Received: 5/10/2020

Revised: $30 / 10 / 2020$

Accepted: 6/11/2020

Published online: 25/01/2021

https://doi.org/10.47869/tcsj.72.1.6

* Corresponding author

Email: quang.dinh@tlu.edu.vn

\begin{abstract}
Saltwater intrusion is one of the most severe problems for worldwide coastal regions, leading to negative impacts on both human and aquatic inhabitant communities. Quang Tri province, located in the Central Coast region of Vietnam, faces consequences of saltwater intrusion because of its dense river network and El Nino phenomena's influences. To analyse hydrological, hydraulic processes as well as investigate saltwater intrusion's situation in this province, the authors adopted MIKE HYDRO River package and obtained results with good agreements with measured data from survey campaigns. The present conditions scenario shows that saltwater intrudes Thach Han and Cam Lo rivers with a distance of $25.35 \mathrm{~km}$ and $15.04 \mathrm{~km}$ respectively, where the salt concentration is under $0.75 \%$ and water can be drunk and irrigated. The large discharge of $30 \mathrm{~m}^{3} / \mathrm{s}$ can only push saltwater only $1.85 \mathrm{~km}$ to the sea, which is insignificant in comparison with the value of seawater wedge length, saltwater intrusion in Thach Han river system can only be mitigated slightly. Since the authors only consider hydrological droughts, future scenarios in 2030 and 2050 have slight differences with the present, where topography and river flow remain unchanged. Based on the above results, nonstructural measurements are not recommended to deal with saltwater intrusion for both present and future scenarios, and local authorities should consider structural solutions, e.g. constructions of anti-salt dams, during the decision-making process.
\end{abstract}

Keywords: Saltwater intrusion, Thach Han river system, MIKE HYDRO River package. 
Transport and Communications Science Journal, Vol. 72, Issue 1 (01/2021), 46-57

\section{INTRODUCTION}

Saltwater intrusion becomes controversial since it has detrimental influences on coastal habitats and human communities [1]. Many pieces of research are implemented to investigate the mechanism and process of this issue. Established by Danish Hydraulic Institute, MIKE HYDRO River, the fully dynamic and one-dimensional modelling package, is considered as an effective tool with several modules to simulate saltwater intrusion and provide good performance with in-situ measurements [2,3].

Quang Tri is one of coastal provinces in the Central of Vietnam, providing enormous benefits for residents in economic, aquaculture and tourism aspects [4]. However, being similar to other central coastal regions in Vietnam, this province is now experiencing negative saltwater intrusions because of hydrological conditions and natural hazards. With the dense river network connecting directly to the sea, the geography is high (1400-2000 m) in the West but relative low in the East, which makes it easier for tidal regime to cause the saltwater intruding to the land through Cua Tung and Cua Viet river mouths [5]. Moreover, due to climate change, El Nino phenomenon in recent years also causes warmer seawater, drought and flood through intense sunshine and strong Southwest wind [6]. As consequences, saltwater intrusion in Quang Tri province becomes extremely severe and this leads to negative problems related to water supply, e.g. agriculture and domestic use, and ecological systems in coastal area. Hence, it is essential for researchers and local authorities to understand the mechanism and affected scope of saltwater intrusion occurring in this province.

The objective of this research is to investigate saltwater intrusion in Thach Han river basin, one of two main river basins in Quang Tri then draw present and future scenarios by adopting MIKE HYDRO River package.

\section{CASE STUDY AND DATA COLLECTION}

\subsection{Case study}

Quang Tri province consists of 7 districts, 1 city and 1 town with total area of $3469 \mathrm{~km}^{2}$ [7] (Fig. 1). This province has complicated topography, including mountainous area in the West and very flat terrain in the East [8]. There are two main river basins namely Ben Hai and Thach Han river basins, which play important roles in provincial livelihoods [9].

Thach Han river system consists of 17 primary rivers, 13 secondary rivers and 6 tertiary rivers. Discharge of river flow fluctuates significantly between seasons, i.e. floods occur in rainy seasons and dry seasons witness drought. In the dry seasons, seawater can easily enter the river due to the low flow, leading to the increasingly severe saltwater intrusion phenomenon. According to a survey in July 2000, when the discharge at Thach Han dam (in Thach Han river) equaled to $12.4 \mathrm{~m}^{3} / \mathrm{s}$, salinity water with the concentration of $4 \%$ reached up to Trieu Giang (junction of Thach Han and Vinh Dinh rivers) [10]. 
Transport and Communications Science Journal, Vol. 72, Issue 1 (01/2021), 46-57

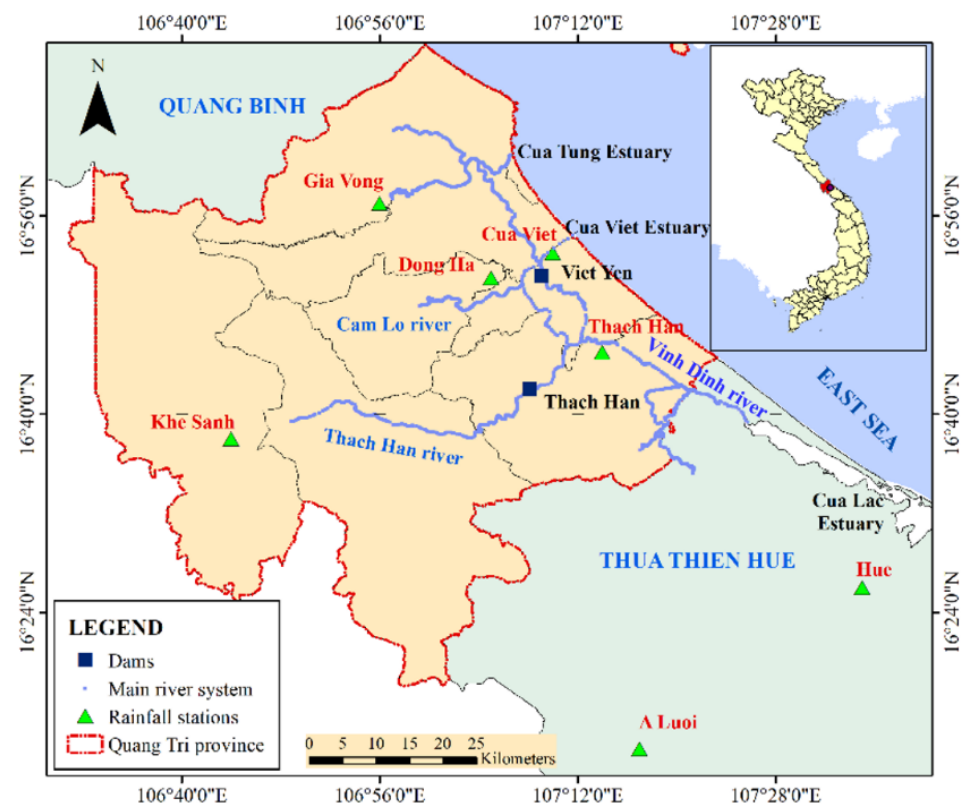

Figure 1. Quang Tri province and Thach Han river system.

\subsection{Data collection}

Topography, meteorological and hydrological data of Quang Tri province were collected as the input to investigate saltwater intrusion in Thach Han river system (Table 1). Topography data includes 1:10,000 scale map from Ministry of Natural Resources and Environment, and Digital Elevation Model with the resolution of $12.5 \mathrm{~m}$ from Advanced Land Observing Satellite (https://www.eorc.jaxa.jp/ALOS/). Meteorological data, i.e. evaporation and rainfall in the period 1986-2018, were retrieved from different stations (see Fig. 1 for their locations). This study also used daily water levels at four stations (i.e. Gia Vong, Dong Ha, Thach Han and Cua Viet), and discharge measured from Gia Vong hydrological station. Moreover, to verify the simulation results, data of tidal and salinity concentration were also collected from 2007 (Fig. 2) and 2017 (Fig. 3) survey campaigns. Noticeably, 2017 saw a deep salinity penetration into Thach Han river, which was about $27 \mathrm{~km}$ from Cua Viet estuary.

Table 1. Main input data for model simulation.

\begin{tabular}{|c|c|c|}
\hline Input Data & Observed Period & Model (Module) \\
\hline Topography and Land use & Period: 2015 & \multirow{4}{*}{ Hydrology (RR) } \\
\hline River discharge & Daily data at Gia Vong station (1986-2018) & \\
\hline Precipitation & Daily data at 7 stations (1986-2018) & \\
\hline Evaporation & $\begin{array}{l}\text { Daily data at Dong Ha and Khe Sanh stations } \\
(1975-2018)\end{array}$ & \\
\hline Hydraulic network & $\begin{array}{l}\text { River network and surveyed cross-sections of } \\
9 \text { rivers }\end{array}$ & \multirow{2}{*}{ Hydraulic (HD) } \\
\hline Tide level & $\begin{array}{l}\text { Hourly data at Cua Viet, Cua Tung and Cua } \\
\text { Lac estuaries (2007 \& 2017) }\end{array}$ & \\
\hline Salinity concentration & $\begin{array}{l}\text { Data at Dong Ha and Cua Viet stations (2007) } \\
\text { and along Thach Han, Cam Lo rivers (2017) }\end{array}$ & $\begin{array}{l}\text { Salinity intrusion } \\
\text { (AD) }\end{array}$ \\
\hline
\end{tabular}




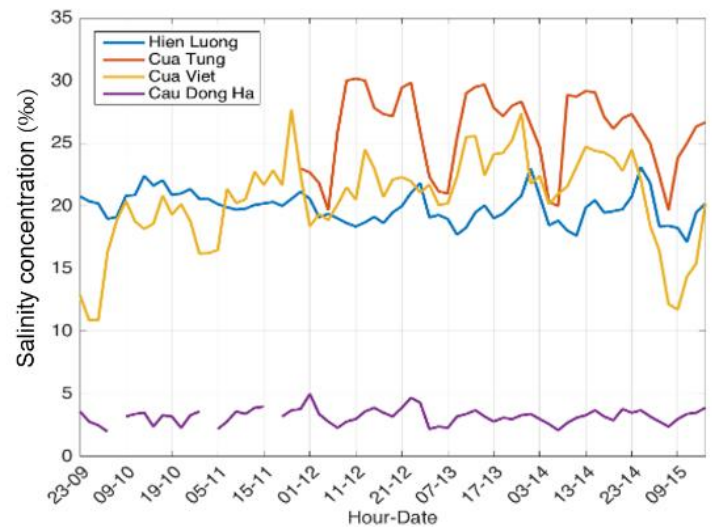

Figure 2. Measured salinity concentration in August, 2007.

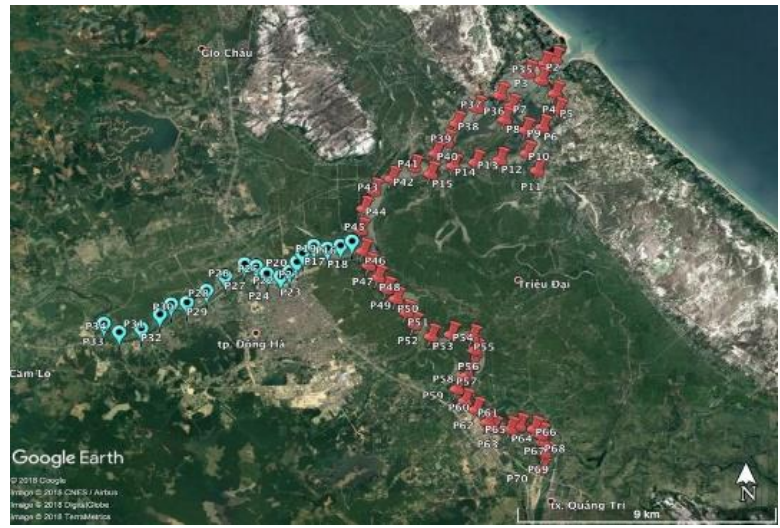

Figure 3.70 surveyed positions in Thach Han and Cam Lo rivers in August, 2017.

\section{METHODOLOGY AND MODELS' DEVELOPMENT}

Fig. 4 shows the conceptual framework of main steps for the study. From collected data in Section 2.2, a set of models for Thach Han river basin was developed based on MIKE HYDRO River package. In order to estimate the natural hydrological processes in the study area, hydrological model with Rainfall-Runoff (RR) module was applied by using meteohydrological and topography [11]. Based on hydraulic works and hydrological model results, hydraulic model with Hydrodynamic (HD) module was required to form a basis of unsteady flow in the river system [1]. Calibration and validation were necessarily conducted for both hydrological and hydraulic models. Finally, simulating salinity intrusion by saline intrusion model with Advection/Dispersion (AD) module was implemented, in which measured salinity concentration data from two campaigns were used for calibration and validation processes. The output of this model was formally used to build a salinity intrusion map as well as to visualize the saline distribution and thresholds in the study area using ArcGIS software. The details of classified thresholds and their effects were described in Table 2.

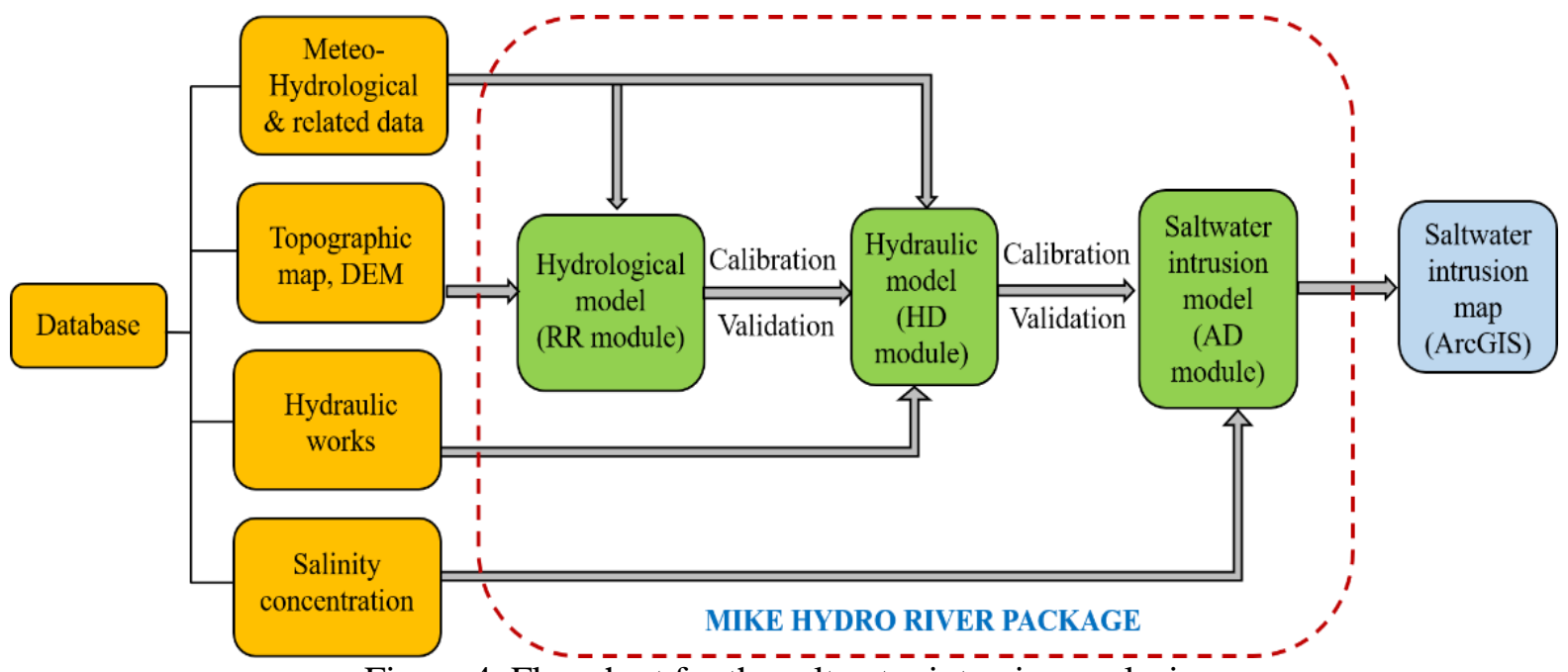

Figure 4. Flowchart for the saltwater intrusion analysis. 
Transport and Communications Science Journal, Vol. 72, Issue 1 (01/2021), 46-57

Table 2. Salinity tolerance [\%] of plants.

\begin{tabular}{cl}
\hline $\begin{array}{c}\text { Threshold } \\
\text { value }\end{array}$ & \multicolumn{1}{c}{ Description } \\
\hline$<\mathbf{0 . 7 5}$ & $\begin{array}{l}\text { Suitable for use with all crops. Little or no effect on the growth and yield of } \\
\text { plants }\end{array}$ \\
\hline $\mathbf{0 . 7 5}-\mathbf{1 . 5}$ & Affects only very sensitive plants, i.e. these plants will suffer some yield loss \\
\hline $\mathbf{1 . 5}-\mathbf{3 . 5}$ & $\begin{array}{l}\text { Affects many plants. Sensitive plants have increasingly reduced growth, } \\
\text { moderately sensitive plants should suffer little or no yield decline }\end{array}$ \\
\hline $\mathbf{3 . 5}-\mathbf{6 . 5}$ & $\begin{array}{l}\text { Affect tolerant plants: moderately sensitive plants will suffer increasing yield } \\
\text { loss. Moderately-tolerant plants should suffer little yield loss with good } \\
\text { management at the lower end of this range. At the upper end, some yield loss } \\
\text { occurs }\end{array}$ \\
\hline $\mathbf{6 . 5 - 8 . 0}$ & Affects even very tolerant plants \\
\hline \hline $\mathbf{3 . 1 6}$
\end{tabular}

\subsection{Hydrological model for Thach Han river basin}

Rainfall-Runoff module was adopted to develop the hydrological model for Thach Han river basin, which was divided into 13 sub-basins (see Fig. 5). To simulate available flow (discharge series), rainfall data at 7 stations and evaporation data at Dong Ha and Khe Sanh stations were imported into the modeled river basin.

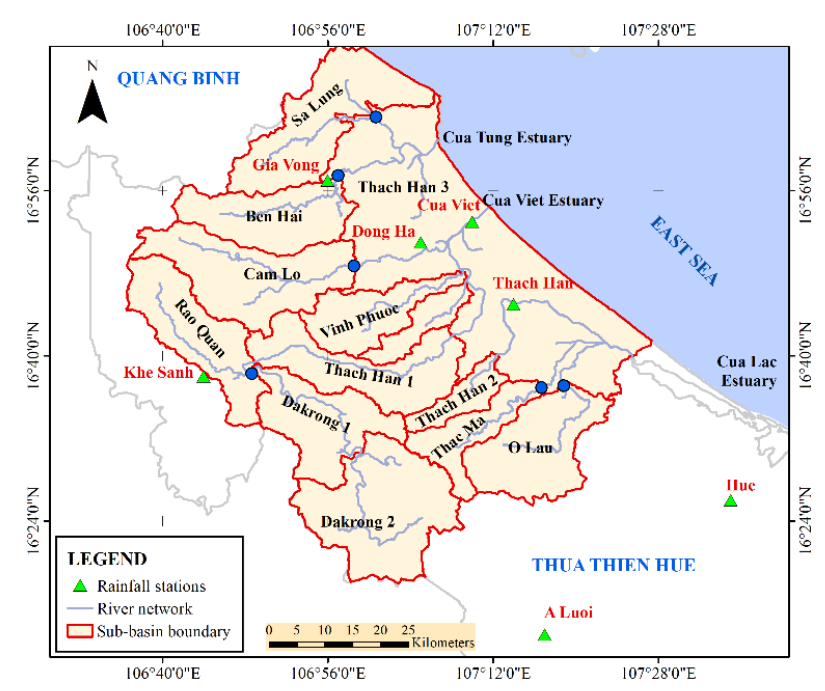

Figure 5. Sub-basins in Thach Han river basin.

During the calibrating process, model parameters automatically adjusted, before being modified individually to obtain the most fitted parameters [10]. The observed discharge at Gia Vong station during periods of 2000-2004 and 2005-2008 was chosen for calibration and validation because there were no big hydraulic structures constructed within the basin. Fig. 6 shows that the simulated runoff (continuous line) fits quite well with the observed one (red circles) in both two periods. The result was acceptable, where the values of coefficient of determination $\left(R^{2}\right)$ in both calibration and validation phases are larger than 0.7 , and the values of Root Mean Square Error (RMSE) and Absolute Mean Difference (AMD) are sufficiently small. It was difficult to achieve better results due to the fact that Ben Hai catchment has only one rainfall station, namely Gia Vong, which coinsides with its outlet. 
Transport and Communications Science Journal, Vol. 72, Issue 1 (01/2021), 46-57
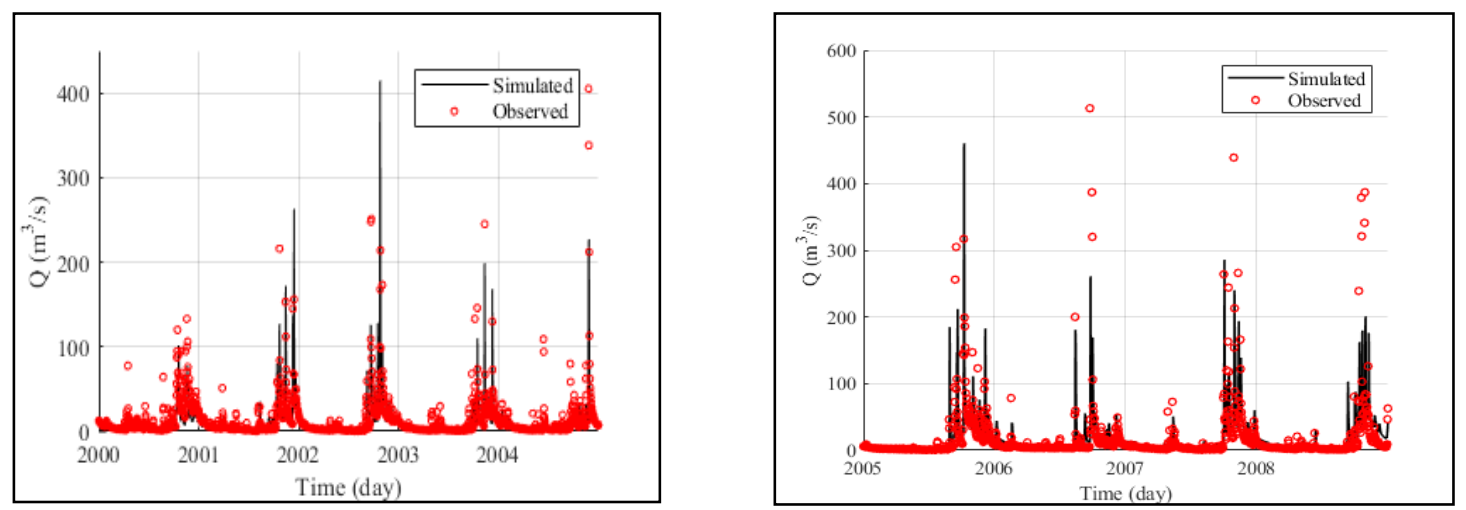

Figure 6. Calibration (left) and validation (right) results of the hydrological model.

Table 3. Some parameters in evaluating calibration and validation results.

\begin{tabular}{cccc}
\hline \hline & $\mathbf{R}^{\mathbf{2}}$ & RMSE & AMD \\
\hline Calibration & 0.729 & $6.451\left[\mathrm{~m}^{3} / \mathrm{s}\right]$ & $1.817\left[\mathrm{~m}^{3} / \mathrm{s}\right]$ \\
\hline Validation & 0.749 & $12.456\left[\mathrm{~m}^{3} / \mathrm{s}\right]$ & $2.147\left[\mathrm{~m}^{3} / \mathrm{s}\right]$ \\
\hline
\end{tabular}

\subsection{Hydraulic model for Thach Han river system}

Hydrodynamic (HD) module was used to develop the hydraulic model for Thach Han river system. The data for this model includes river network, cross-sections and boundary conditions. More precisely, the boundary conditions include the upper, lateral (discharge) and lower boundaries (water level). In this study case, upstream boundary comprises runoff at six outlets of Sa Lung, Ben Hai, Cam Lo, Dakrong, Thac Ma and O Lau sub-basins (see blue points in Fig. 5 and Fig. 7). Water levels at Cua Viet, Cua Tung and Cua Lac estuaries were used as downstream boundary conditions. In addition, the lateral boundary condition is the simulated flow in Thach Han 1 sub-basin (see Fig. 5).

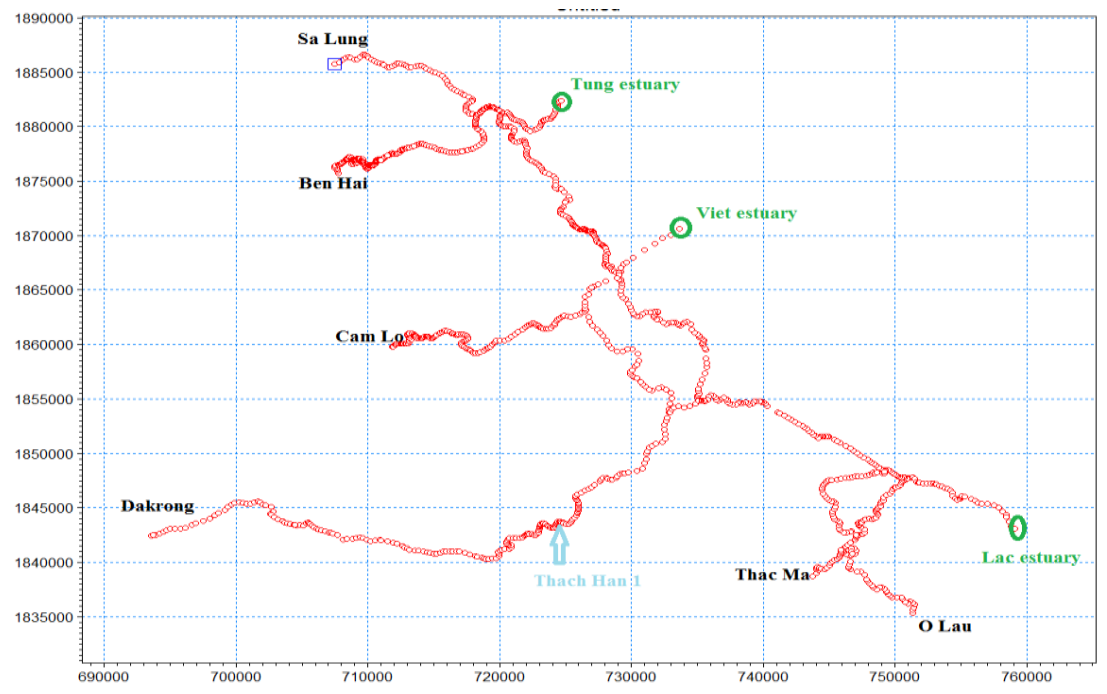

Figure 7. River network and boundary conditions in the hydraulic model.

The model was well calibrated and validated by using observed time series of water levels at Thach Han station in 2009 and 2013 (red lines) and simulated ones (blue lines), showing good agreement as shown in Fig. 8. 
Transport and Communications Science Journal, Vol. 72, Issue 1 (01/2021), 46-57
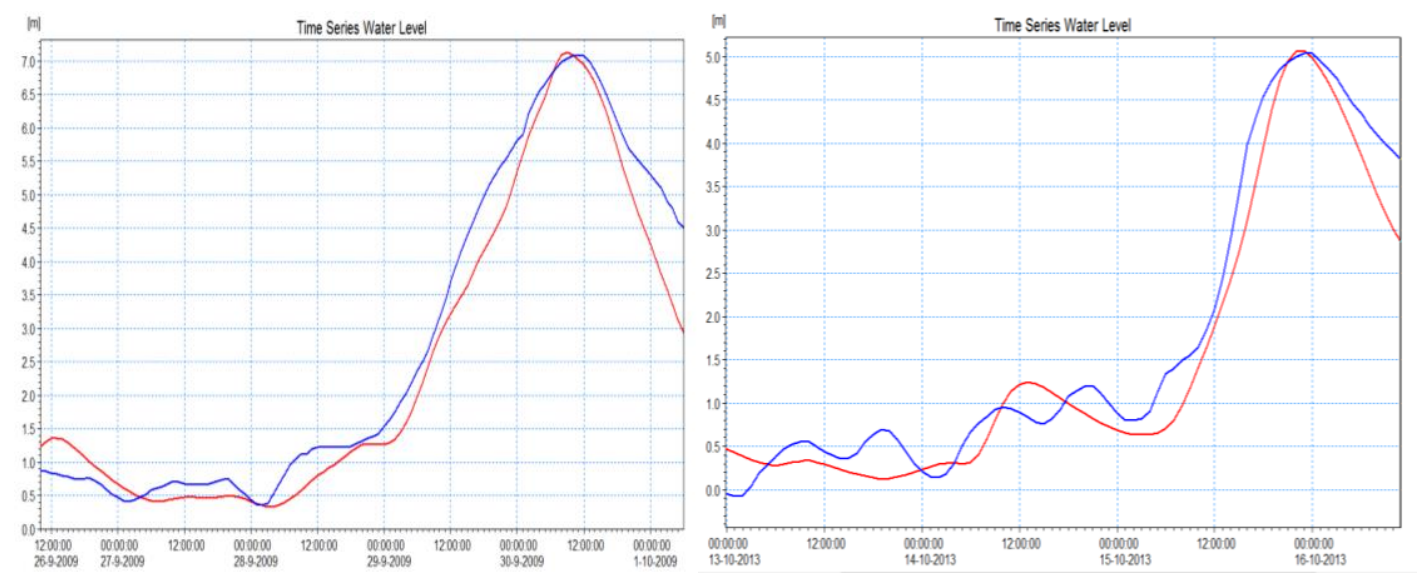

Figure 8. Calibration (left) and validation (right) results of the hydraulic model.

\subsection{Saltwater intrusion model for Thach Han river system}

One-dimensional transport of saltwater in Thach Han river system was simulated by using Advection-Dispersion module in MIKE HYDRO River package. To establish the suitable calculation domain for the model, the authors firstly simulated the most extreme case, i.e. the flow of zero at the upstream boundaries, the highest tidal levels and the greatest salinity concentration (33\%) at the estuaries. The chosen domain for this model only consists of Thach Han and Cam Lo rivers for an accessible simulation (Fig. 9). It is worthwhile noting that the construction of Vinh Yen (in Vinh Yen river) and Thach Han (in Thach Han river) anti-salt dams had prevent the saltwater migrating further upstream; and saltwater has not been intruded to Cam Lo town [12].

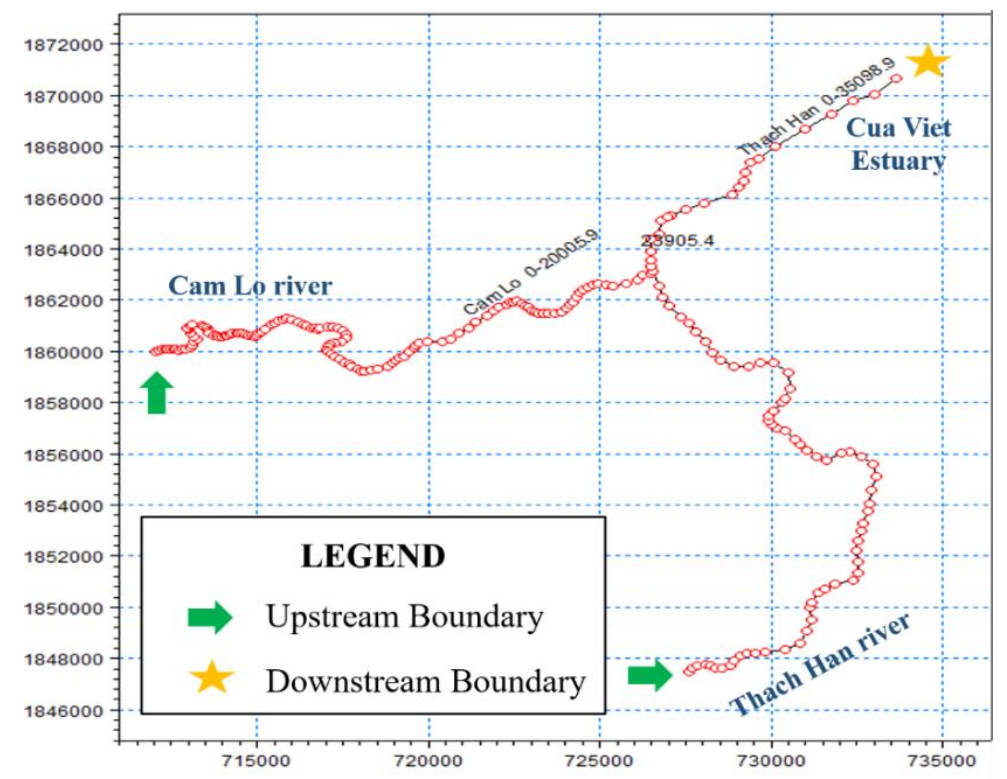

Figure 9. Simulated river network in the saltwater intrusion model.

The model was calibrated by comparing simulated (blue line) and measured (red circles) salinity concentration in August, 2007 at Dong Ha station (see Fig. 10), showing good agreement between these values. For the validation of salinity longitudinal profile, the authors used the salinity data along Thach Han and Cam Lo rivers measured on August $12^{\text {th }}, 2017$, when spring tide and the deepest saline intrusion occurred. During this survey campaign, salinity was measured from point $P 1$ (at Cua Viet estuary) to point $P 70$ (about $27 \mathrm{~km}$ from Cua 
Viet estuary) that was not affected by salinity (see Fig. 3 for their locations). The simulated results of the model show good agreement with those measured data, since the seawater wedge length obtained from saltwater intrusion model is $27.2 \mathrm{~km}$, which is about $7.8 \mathrm{~km}$ downstream from Thach Han dam (see Fig. 11) and relatively matched with the location of $P 70$. The same performance was also obtained in the case of Cam Lo river.

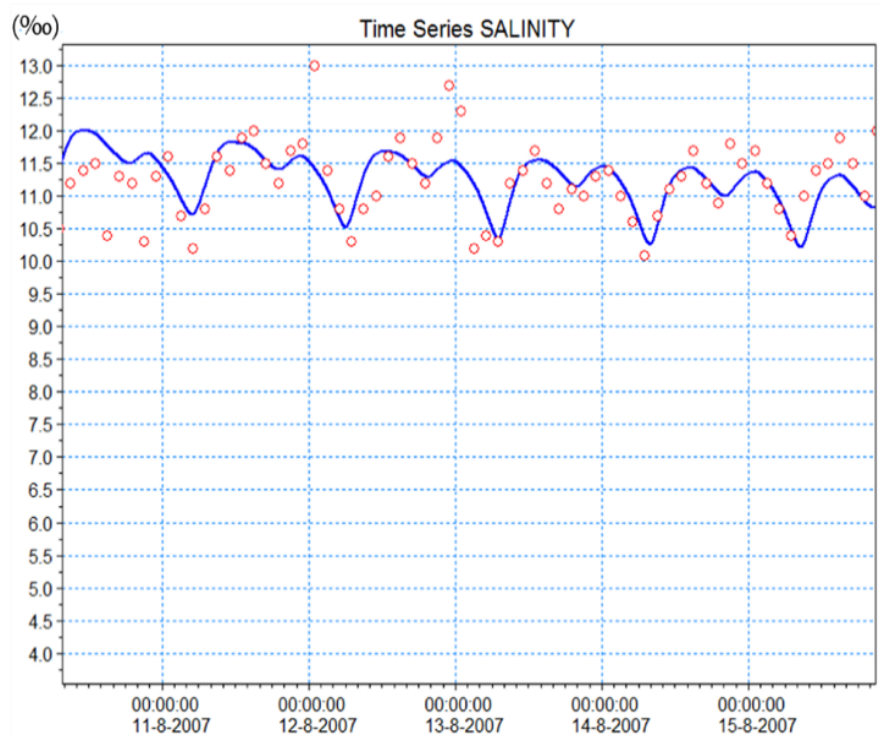

Figure 10. Comparison between simulated and measured salinity concentration at Dong Ha station.
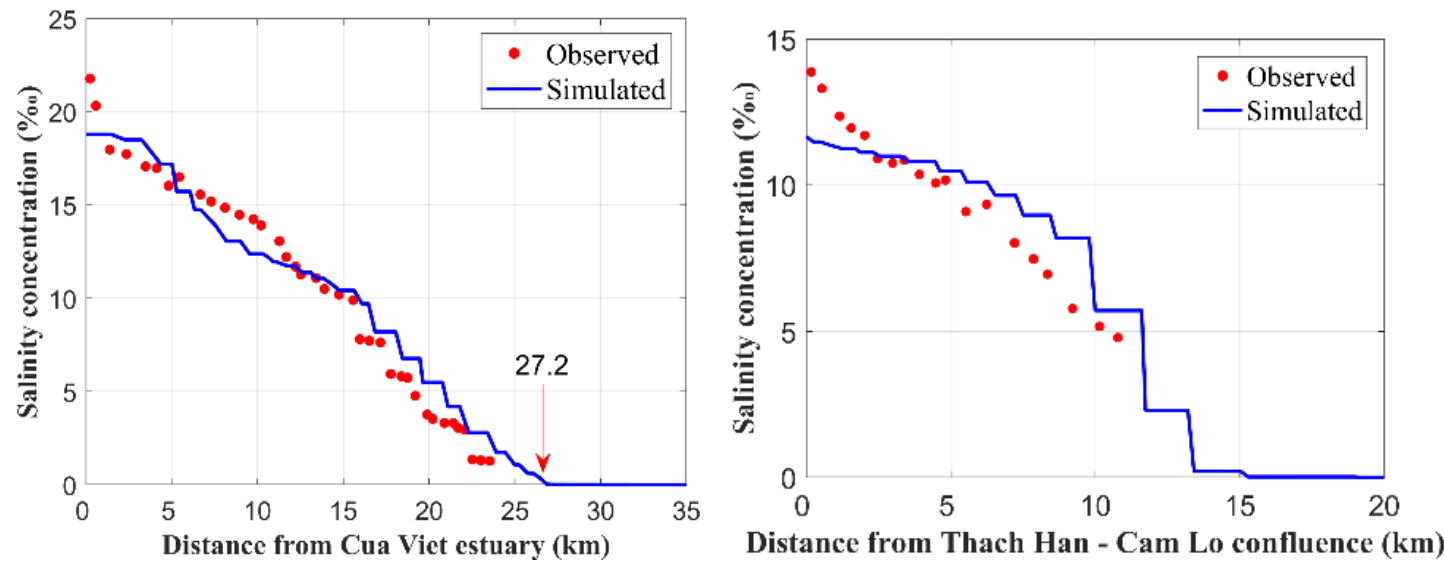

Figure 11. Simulated and measured salinity on August $12^{\text {th }}, 2017$ along Thach Han (left) and Cam Lo (right) rivers.

\section{RESULTS AND DISCUSSION}

Different scenarios of saltwater intrusion were drawn by focusing on hydrological droughts and low flow in the river. The authors considered the relationship between seawater wedge length and different salinity thresholds. Noticeably, each value range of this threshold has different impacts on plants (Table 2). For the threshold of $0.75 \%$, water is able to be used for both drinking and irrigation of all crops without any negative effect. In contrast, if water has larger than $6.5 \%$ in salinity, it is even unable to be used for plants. Thus, with a long distance of seawater intruding from the sea, water supply may not meet the quality for exploiting purposes, e.g. water usage and irrigation. 
In designing the flow in the river, the flow duration curves at upper and lateral boundaries, i.e Thach Han and Cam Lo, were built (Fig. 12). To determine the value of simulated flow, the authors adopted the flow duration curve for Thach Han and Cam Lo rivers. This curve shows the percent of time, when specified discharge equals or exceeds during a given period. Therefore, if the period upon which the curve is based represents the long-term flow of a stream, the curve may be used to predict the distribution of future flows for salt intrusion study. In this study the period of 274 days was chosen for extracting discharge values which represent low flow conditions. Some low-flow-condition years are extracted from relevant simulated discharge time series and their flow duration curves were built. The design low flow is the average flow at a period of 274 days of these curves. This means that the discharge values exceed $75 \%$ of the time (274 days/365days). Under future scenarios (2030 and 2050), the same procedure was applied. The design flow in these conditions does not change significantly over time (Table 4).

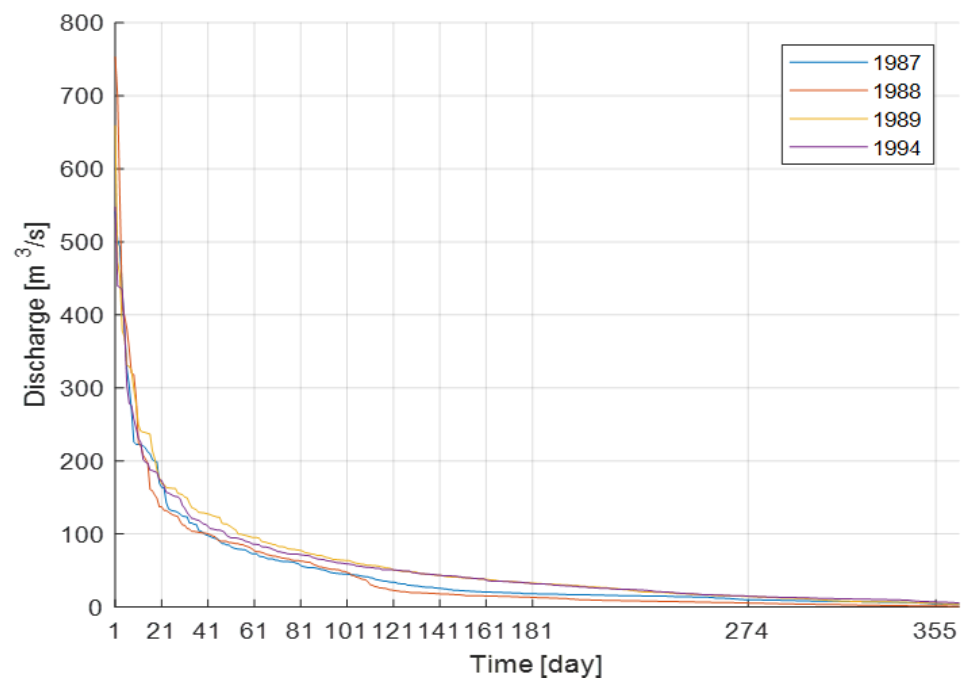

Figure 12. Flow duration curve at Thach Han.

Table 4. Upstream flow values $\left(\mathrm{m}^{3} / \mathrm{s}\right)$.

\begin{tabular}{ccc}
\hline \hline Scenario & Thach Han river & Cam Lo river \\
\hline Present & 1.92 & 1.20 \\
\hline 2030 & 1.18 & 1.00 \\
\hline 2050 & 1.26 & 1.05 \\
\hline \hline
\end{tabular}

\subsection{Saltwater intrusion in present conditions}

For present conditions, Table 5 and Fig. 13 show the salinity intrusion length along Thach Han and Cam Lo rivers corresponding to different salinity thresholds. Noticeably, each value range of this threshold has different impacts on plants (see Table 2). For the threshold of $0.75 \%$, water is able to use for both drinking and irrigation of all crops without any negative effect. In contrast, if water has larger than $6.5 \%$ in salinity, it is even unable to use for plants. About $18.16 \mathrm{~km}$ of Thach Han river and $9.8 \mathrm{~km}$ of Cam Lo river (where salinity concentration is greater than $8.0 \%$ ), water in these rivers can affect tolerant plants detrimentally. For the demand for both drinking and irrigation of all crops without any negative effect, local people may exploit water at seawater wedge length of $25.35 \mathrm{~km}$ and $15.04 \mathrm{~km}$ for Thach Han and Cam Lo 
rivers respectively, where the salinity concentration is less than $0.75 \%$.

Released water from upstream is one of the non-structural measurements that can effectively deal with the issue of saltwater intrusion due to its ability to push salinity water toward the sea. According to the simulated results of the saltwater intrusion model, the release of $10 \mathrm{~m} 3 / \mathrm{s}$ can only push seawater $0.82 \mathrm{~km}$ toward the sea, and the distance pushed by the even more massive flow of $30 \mathrm{~m}^{3} / \mathrm{s}$ is only $1.85 \mathrm{~km}$. These values are insignificant compared with the intruded length, and the release of $30 \mathrm{~m}^{3} / \mathrm{s}$ is infeasible in reality. Thus, other solutions, e.g. constructions of anti-salt dams, should be considered.

Table 5. Seawater wedge length $(\mathrm{km})$ in two rivers corresponding to different salinity thresholds.

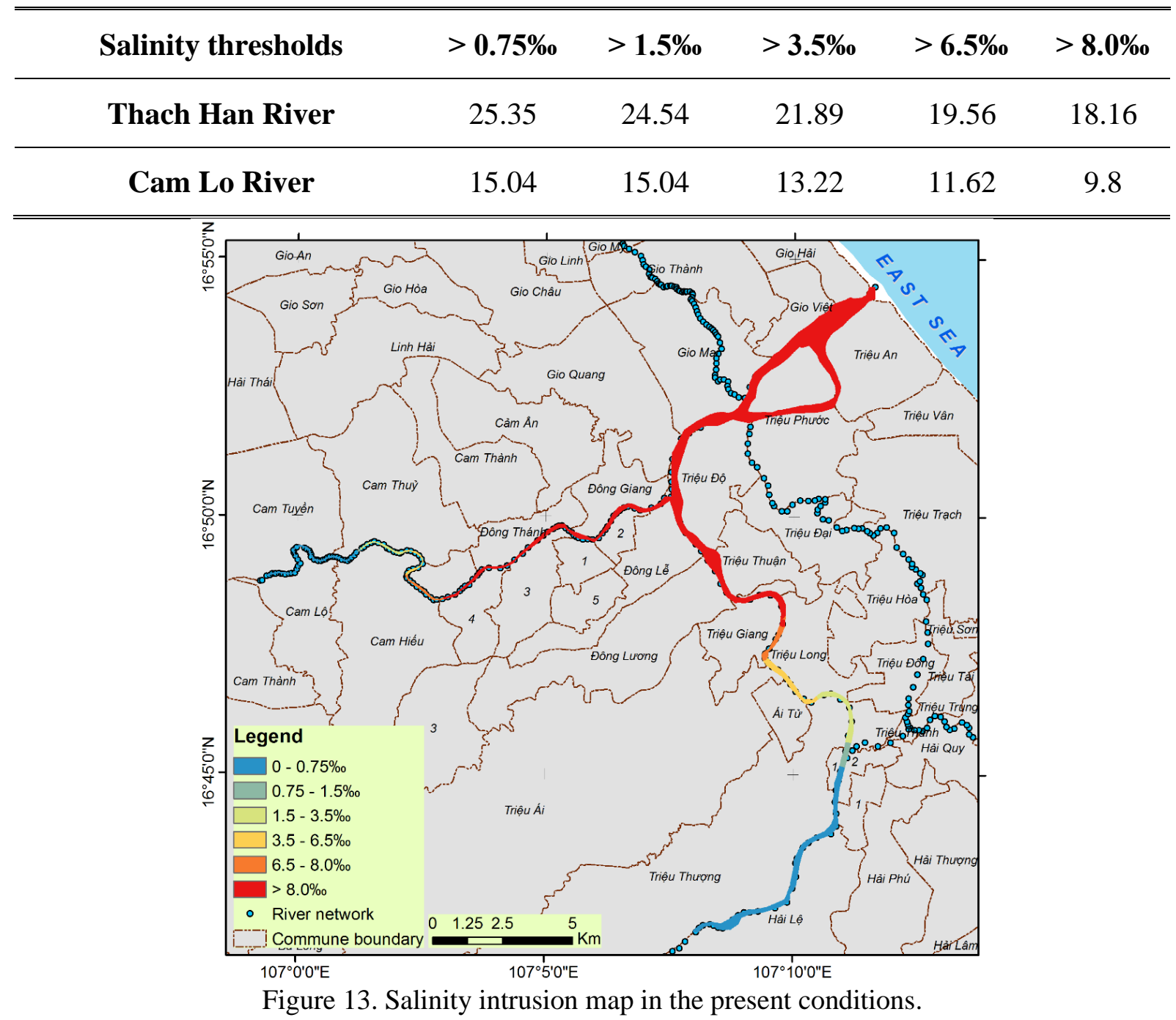

\subsection{Saltwater intrusion under future scenarios}

The future scenarios in 2030 and 2050 were drawn with the difference only in upstream flow values (Table 4), by focusing only on the hydrological drought. The simulation results reveal that the saltwater intrusion situation under future scenarios, is almost the same as present situation. This is due to the fact that the difference between upstream flows under different scenarios is only less than $1 \mathrm{~m}^{3} / \mathrm{s}$; while with the massive release of $30 \mathrm{~m}^{3} / \mathrm{s}$, the seawater wedge length only reduces by $1.85 \mathrm{~km}$. Since the seawater wedge length was predicted not to be 
Transport and Communications Science Journal, Vol. 72, Issue 1 (01/2021), 46-57

impacted too much under hydrological drought in the future, the local people could exploit water at recommended location as in present condition.

\section{CONCLUSION}

Vietnam is now suffering the detrimental impacts of saltwater intrusion, and the Central region, particularly Quang Tri province, is one of the most influenced area. In this study, the authors adopted MIKE HYDRO River package to develop hydro-logical, hydraulic and saltwater intrusion models to investigate saltwater intrusion for Thach Han river system. After the calibration and validation processes, the simulated results of those models achieve good correlations in comparison with measured data. Particularly, the seawater wedge length simulated from saltwater intrusion model was $27.2 \mathrm{~km}$ from Cua Viet estuary, while the one collected from the survey campaign was $27 \mathrm{~km}$. In present condition, the authors indicated the seawater wedge length, where the salinity concentration is less than $0.75 \%$ and water is able to drink and irrigate, of Thach Han and Cam Lo rivers are $25.35 \mathrm{~km}$ and $15.04 \mathrm{~km}$, respectively. Considering the relationships between releases from upstream and saltwater intrusion situation, the significant release, e.g. $30 \mathrm{~m}^{3} / \mathrm{s}$, can reduce seawater wedge length slightly, which is insignificant with the intruded length. From these findings and saltwater intrusion maps visualised by ArcGIS software, decision-makers can have the basis to offer suitable and optimal solutions to deal with saltwater intrusion consequences in the present and future scenarios.

\section{REFERENCES}

[1]D. N. Quang et al., On the Control of Saltwater Intrusion: A Case Study for Binh Thuan Province, Vietnam, in APAC 2019, Singapore, 2020, pp. 1469-1476. https://doi.org/10.1007/978-981-15-0291$\underline{0 \_198}$

[2]D. T. Vu, T. Yamada, H. Ishidaira, Assessing the impact of sea level rise due to climate change on seawater intrusion in Mekong Delta, Vietnam, Water Sci. Technol., 77 (2018) 1632-1639. https://doi.org/10.2166/wst.2018.038

[3]K. Tully et al., The Invisible Flood: The Chemistry, Ecology, and Social Implications of Coastal Saltwater Intrusion, BioScience, 69 (2019) 368-378. https://doi.org/10.1093/biosci/biz027

[4] M. Krutwagen, Impact of shrimp pond wastewater on the estuaries and the issue of salinity intrusion in the Quang Tri Province, 2007.

[5]N. T. Sao et al., Structural measures to restore Cua Tung beaches, Quang Tri province, VNU J. Sci. Earth Environ. Sci., 26 (2010) 98-103. https://js.vnu.edu.vn/EES/article/view/1780

[6] VnExpress, El Nino looms large in 2017 with drought and strong typhoons forecast for Vietnam VnExpress International, VnExpress International - Latest news, business, travel and analysis from Vietnam, $2017 . \quad$ https://e.vnexpress.net/news/news/el-nino-looms-large-in-2017-with-drought-and-strongtyphoons-forecast-for-vietnam-3560262.html

[7]Quang Tri Statistics Office, Quang Tri Statistical Yearbook 2015, 2015.

[8]M. Van Vilsteren, Design flood estimation for the Quang Tri Province in Vietnam, 2010. http://purl.utwente.nl/essays/69461 
Transport and Communications Science Journal, Vol. 72, Issue 1 (01/2021), 46-57

[9] M. Krutwagen, Impact of shrimp pond wastewater on the estuaries and the issue of salinity intrusion in the Quang Tri Province, 2007. https://essay.utwente.nl/68661/1/Krutwagen-Michiel.pdf

[10] Institute of Water Resources Planning, Water resources planning in Thach Han - O Lau basin Report on current situation of economic and social development, 2006.

[11] N. Agrawal, T. S. Desmukh, Rainfall Runoff Modeling using MIKE 11 Nam - A Review, 3 (2016) 659-667. http://ijiset.com/vol3/v3s6/IJISET_V3_I6_87.pdf

[12] Saltwater intrusion is beyond $10 \mathrm{~km}$ from Dong Ha city, Quang Tri province, 2020. https://nongnghiep.vn/quang-tri-man-xam-nhap-vuot-qua-thanh-pho-dong-ha-10-km-d161746.html 